\title{
occurence of bacterial urinary tract infection in hand reared lesser anteaters (tamandua tetradactyla): case report*
}

\section{Ocorrência de infecção bacteriana em trato urinário de tamanduás-mirim (Tamandua tetradactyla) criados artificialmente: relato de caso}

\author{
Laura Reisfeld, ${ }^{* *}$ Bruna Silvatti, ${ }^{* *}$ Ana Carolina Soares, ${ }^{* *}$ Alice Reisfeld ${ }^{* *}$
}

\begin{abstract}
On October, 2009 and on May, 2011, two orphan lesser anteaters, with approximately two and five months of age, respectively, were received at the Aquário de São Paulo. Both were hand reared. Urine analysis were performed on both animals, and changes such as hematuria, pyuria and bacteria were observed. The treatment plan was chosen aiming to acidify the urine, eliminate the crystals and the bacterial infection. The antibiotics that were used were chosen according with the antibiograms' result. Preventive medicine programs are being performed frequently with the intention of establishing reference parameters of extreme relevance for the maintenance of this species in captivity. In the case of anteaters, who present low intrinsic rates of population growth, the maintenance of a minimum viable population is utterly necessary.
\end{abstract}

Keywords: captivity, infection, Tamandua tetradactyla, urinary tract.

\begin{abstract}
Resumo
O Tamanduá-mirim (Tamandua tetradactyla) apresenta grande distribuição, ocorrendo praticamente em todos os biomas brasileiros. Os exemplares mantidos na maioria dos zoológicos são oriundos de vida livre. As principais doenças que acometem os tamanduás mantidos em cativeiro são: deficiência de taurina, vitamina $\mathrm{K}$ e A, traumas, enterites bacterianas, pneumonias bacterianas e dermatites. Em outubro de 2009 e em maio de 2011, foram recebidos no Aquário de São Paulo, dois filhotes de tamanduá-mirim (Tamandua tetradactyla) com aproximadamente dois e cinco meses de idade. Ambos criados artificialmente. Foram realizados exames de urina, onde alterações como hematúria, piúria e bactérias puderam ser observadas. O tratamento visou a acidificação da urina, a eliminação dos cristais e da infecção bacteriana. Os antibióticos utilizados foram escolhidos de acordo com o resultado do antibiograma. Manejo de medicina preventiva está sendo realizado com freqüência com o intuito de estabelecer parâmetros de referências de extrema relevância para a manutenção desta espécie em cativeiro. No caso dos tamanduás, que apresentam baixas taxas intrínsecas de crescimento populacional, a manutenção de uma população mínima viável em cativeiro se torna cada vez mais necessária.
\end{abstract}

Palavras-chave: cativeiro,infecção, Tamandua tetradactyla, trato urinário.

\section{Introduction}

Anteaters belong to the order Xenarthra, which includes four families, one genus and 29 species (Wetzel, 1985). The Lesser anteater (Tamandua tetradactyla) is distributed along the east of the Andes, from the south of Venezuela to the North of Argentina and Uruguay. In Brazil, it occupies all the biomes (Amazon, Caatinga, Cerrado, Atlantic Forest, Pantanal and Pampa) (Medri et al., 2006; Miranda and Costa, 2006; Tavares and Koenemann, 2008; Batista, 2009).

The intensity of the exploitation of natural resources has been putting the possibilities of natural renewal at risk. According to Costa et al. (2005), habitat loss, degradation and fragmentation resulting from human activities are the main threats to terrestrial mammals in Brazil. The lesser anteater's fragility and its visible disappearance from certain regions, including its original geographical range, clearly show the necessity of measures that can assure its protection (WCS 2011). Since many wild lesser anteaters are rescued in Brazil due to the expansion of human population in natural areas, most of the individuals kept in Brazilian zoos came from the wild (Diniz, 1995). In this sense, maintaining a healthy population in captivity is extremely important for the conservation of the species.

The main diseases reported in captive anteaters are: taurine, vitamin $\mathrm{K}$ and A deficiency, traumas, bacterial enteritis, bacterial pneumonias and dermatitis. Urinary tract infections are poorly described. According to Diniz, 1995, who analyzed 200 different disease cases in anteaters, only two animals showed some kind of urinary disturbance. In another survey, it was stated that in 74 dead animals, only $1,3 \%(1 / 74)$ of the animals showed renal insufficiency (Miranda and Costa, 2006).

${ }^{*}$ Recebido em 6 de dezembro de 2012 e aceito em 13 de maio de 2013.

**Aquário de São Paulo - e-mail para contato: lauravet@aquariodesaopaulo.com.br. 
Bacterial urinary tract infections typically results from normal skin and $\mathrm{Gl}$ tract flora ascending the urinary tract and overcoming the normal urinary tract defenses that prevent colonization (Kahn and Line, 2005). Studies that demonstrate the normal bacterial flora of the urinary tract of these species are lacking (Ware, 2006).

In most mammals, the urine's $\mathrm{pH}$ can vary from 4.5 to 8 , however, due to metabolic activities; it is usually more acidic, ranging from 5.5 to 6.5. Protein ingestion and citric fruits can cause more acidic urine, while citrates can cause more alkaline urine (Sheets and Lyman, 1986).

The consequences of a non treated urinary tract infection includes inferior urinary tract dysfunction, urolythiasis, infertility, septicemia, pyelonefritis and eventually, renal failure (Kahn and Line, 2005).

The objective of this study is to describe a urinary tract infection case in two hand-reared lesser anteaters.

\section{Case Report}

\section{Case 1}

In October, 2009, the Aquário de São Paulo, Brazil received a female Lesser anteater (Tamandua tetradactyla), with approximately 2 months of age and weighing $718 \mathrm{~g}$. The diet offered to the animal was primarily composed of a Milk substitute for dogs and cats (Pet Milk®) and Ensure $®$. This diet was gradually replaced and the new composition was: ground meat, Gastrintestinal dry dog food (Royal Canin $®$ ), spinach, apple, beet, carrot, tomato, banana, egg and water. All the ingredients were placed in a mixer in order to get a soft consistency. This diet was offered at intervals of 2 to 3 hours. The animal was daily supplemented with vitamin $\mathrm{K}(5 \mathrm{mg} / \mathrm{kg})$ and Taurine $(250 \mathrm{mg} /$ day).

After 6 months from its arrival, the animal started showing frequent hematuria and excessive licking and suction of genital area. This behavior was mainly observed when the animal was not with her keepers or while sleeping. To evaluate her clinical condition, exams such as CBC (Complete Blood Count), kidney and liver panel, ultrasound and urinalysis were performed. On the CBC, liver and kidney panel no alterations were observed (values obtained were compared with reference values for the species). The bladder could be visualized on the ultrasound and did not show any sign of lithiasis or any other significant alteration. To collect urine samples, the animal was conditioned to urinate always in the same place, previously prepared to an aseptic collection. Once collected, the urine was stored in a refrigerated place until the sample processing (always performed in the same day).

Physical-chemical analysis and bacteriological cultures of aerobic and facultative anaerobic were performed. On the first exam, the bacterial isolates from the culture were Escherichia coli, Staphylococcus $s p$ and Non hemolytical Streptococcus. Other changes observed were erythrocytes and leukocytes on the urine (hematuria and pyuria) and keratinized epithelial cells. According to the urinalysis, bacterial culture results and clinical signs such as hematuria, a treatment plan was recommended for this animal.

The treatment plan aimed to eliminate the bacterial infection and the triple phosphate crystals. The antibiotics used on the first treatment were Amoxicillin + Clavulanic Acid (2,4 mgkg, every 15 hours) and Enrofloxacin (1 $\mathrm{mg} k \mathrm{~kg}$, every 14 hours). Due to a relapse of the infection, another treatment based on the results of the antibiogram was performed. On the second treatment the antibiotic of choice was Cefalexin ( $4,5 \mathrm{mg} \mathrm{kg}$, every 8 hours). The dosage and frequency of administration was calculated through allometric scale, as described by Pachaly, 2006, using a $5,0 \mathrm{~kg}$ cat as animal model. The choices of the antibiotics were based on the antibiogram's results. Apple cider vinegar and orange juice were added to the diet to acidify the urine, helping on the elimination of the triple phosphate crystals.

During 5 months after detection of urinary tract infection, urine exams were performed frequently to monitor the control or the relapse of the infection (Table 1).

The treatment lasted for approximately 2 months and was only ceased after negative results of bacteriological cultures and after the elimination of triple phosphate crystals. The animal did not show any signs of apathy or decrease in appetite.

\section{Case 2}

In May, 2011, the Aquário de São Paulo received another Lesser anteater, male, with approximately 5 months of age, weighing $1,160 \mathrm{~kg}$. On the physical exam performed on its arrival, a lesion due to excessive licking on the genital area was observed. The diet offered to this animal was composed of ground beef heart, Gastrintestinal dry dog food (Royal Canin®), flax seed oil, honey, papaya, banana, tomato, spinach, egg and water. All the ingredients were placed in a mixer in order to get a soft consistency. This diet was offered every 2 hours. The animal was daily supplemented with vitamin $\mathrm{K}(5 \mathrm{mg} / \mathrm{kg})$ and Taurine (250 mg/day).

Before sleeping, or when it was not with his keepers, the animal showed the same behavior presented by the first animal, excessive licking and suction of the genital area.

Due to observations regarding the animal's behavior, it was possible to define when the animal would urinate; making it possible to prepare an aseptic recipient that was placed under the animal to collect a proper urine sample.

Physical-chemical analysis and bacteriological cultures of aerobic and facultative anaerobic were performed. On the first exam, bacterial culture isolates were Staphylococcus sp and Non hemolytical Streptococcus. Other changes observed were leukocytes on the urine (pyuria), keratinized epithelial cells and more alkaline urine (Table 2).

According to the urinalysis, bacterial culture results and clinical signs a treatment plan was recommended for this animal.

The treatment plan was aimed to eliminate the bacterial infection and the triple phosphate crystals, avoiding the accumulation of the same. The antibiotic used on the first treatment was Cefalexin (4,6 mgkg, every 8 hours). The dosage and frequency of administration was calculated through allometric scale, as described by Pachaly, 2006, using a 5,0 kg cat as animal model. The choice of the antibiotic was based on the antibiogram's results. Apple cider vinegar and orange juice were added to the diet to acidify the urine, helping on the elimination of the triple phosphate crystals.

Environmental enrichment items were also offered daily to decrease the excessive licking of the genital area behavior.

After the end of the treatment, a new urinalysis was performed to verify the effectiveness of the treatment. 
Table 1: Urynalys, Bacteriological results and treatment of a captive young female Lesser anteater (Tamandua tetradactyla), SP.2009

\section{URINALYSIS CASE 1}

\begin{tabular}{|c|c|c|c|c|c|c|c|c|}
\hline & $01 / 03 / 10$ & $11 / 03 / 10$ & $19 / 03 / 10$ & $22 / 03 / 10$ & $19 / 04 / 10$ & $26 / 04 / 10$ & $14 / 05 / 10$ & $22 / 07 / 10$ \\
\hline Volume & $6 \mathrm{ml}$ & $15 \mathrm{ml}$ & $6 \mathrm{ml}$ & $3 \mathrm{ml}$ & Urine Culture & $3 \mathrm{ml}$ & $1 \mathrm{ml}$ & $3 \mathrm{ml}$ \\
\hline Color & Citrine yellow & Golden yellow & $\begin{array}{l}\text { Golden } \\
\text { yellow }\end{array}$ & $\begin{array}{l}\text { Golden } \\
\text { yellow }\end{array}$ & - & Light amber & $\begin{array}{l}\text { Straw } \\
\text { yellow }\end{array}$ & Straw yellow \\
\hline Aspect & Clear & Clear & Clear & Clear & - & Clear & Clear & Clear \\
\hline Odor & Sui generis & Sui generis & Sui generis & Sui generis & - & Sui generis & Sui generis & Sui generis \\
\hline Density & 1040 & 1018 & 1038 & 1038 & - & 1020 & 1026 & 1028 \\
\hline ph & 6.5 & 7.5 & 6.5 & 6.5 & - & 5.0 & 5.0 & 6.0 \\
\hline Nitrites & Negative & Negative & Negative & Negative & - & Negative & Negative & Negative \\
\hline Protein & Negative & Negative & Negative & Negative & - & Negative & Negative & Negative \\
\hline Glucose & Negative & +-- & Negative & Negative & - & Negative & +-- & ++++ \\
\hline Ketones & Negative & Negative & Negative & Negative & - & Negative & Negative & Negative \\
\hline Urobilinogen & Negative & Negative & Negative & Negative & - & Negative & Negative & Negative \\
\hline Bilirrubin & Negative & Negative & Negative & Negative & - & Negative & Negative & Negative \\
\hline Hemoglobin & Negative & ++++ & +++ & Negative & - & +++ & +-- & Negative \\
\hline Erythrocytes & $0-1$ & $0-2$ & $0-1$ & $0-1$ & - & $1-3$ & $3-5$ & Rare \\
\hline Leukocytes & Rare & Rare & Rare & $0-2$ & - & $0-2$ & $1-3$ & Rare \\
\hline Cylinders & Absent & Absent & Absent & Absent & - & Absent & Absent & Absent \\
\hline Crystals & $\begin{array}{l}\text { Triple } \\
\text { Phosphate } \\
\text { Crystals+-- }\end{array}$ & $\begin{array}{l}\text { Triple } \\
\text { Phosphate } \\
\text { Crystals+-- }\end{array}$ & $\begin{array}{l}\text { Triple } \\
\text { Phosphate } \\
\text { Crystals ++- }\end{array}$ & $\begin{array}{l}\text { Amorphous } \\
\text { urate +-- }\end{array}$ & - & Absent & Absent & $\begin{array}{l}\text { Amorphous } \\
\text { urate +-- }\end{array}$ \\
\hline Cells & $\begin{array}{l}\text { Vesicles +-- } \\
\text { Keratinized } \\
\text { epithelial } \\
+--\end{array}$ & $\begin{array}{l}\text { Keratinized } \\
\text { epithelial } \\
+--\end{array}$ & $\begin{array}{l}\text { Keratinized } \\
\text { epithelial } \\
+-\end{array}$ & Vesicles +-- & - & $\begin{array}{l}\text { Keratinized } \\
\text { epithelial } \\
+--\end{array}$ & $\begin{array}{l}\text { Keratinized } \\
\text { epithelial } \\
+-\end{array}$ & $\begin{array}{l}\text { Keratinized } \\
\text { epithelial } \\
+--\end{array}$ \\
\hline Bacteria & Positive & Negative & Negative & Negative & Positive & Positive & Negative & Negative \\
\hline $\begin{array}{l}\text { Bacterial } \\
\text { culture }\end{array}$ & $\begin{array}{l}\text { Escherichia coli } \\
\text { Staphylococcus } \\
\text { sp } \\
\text { Non hemolytic } \\
\text { Streptococcus }\end{array}$ & -- & -- & -- & $\begin{array}{l}\text { Staphylococcus sp } \\
\text { Non-hemolytic } \\
\text { Streptococcus }\end{array}$ & $\begin{array}{l}\text { Staphylococcus } \\
s p \text { Streptococcus }\end{array}$ & -- & -- \\
\hline Obs & & --- & --- & --- & $\begin{array}{l}\text { Only urine culture } \\
\text { performed }\end{array}$ & --- & $\begin{array}{l}\text { Animal } \\
\text { was not } \\
\text { fasting }\end{array}$ & $\begin{array}{l}\text { Animal was } \\
\text { not fasting }\end{array}$ \\
\hline Treatment & $\begin{array}{l}\text { Amoxicillin + } \\
\text { Clavulanic acid } \\
+ \text { Enrofloxacine }\end{array}$ & $\begin{array}{l}\text { Amoxicillin } \\
+ \text { Clavulanic } \\
\text { acid }+ \\
\text { Enrofloxacine }\end{array}$ & -- & & Cefalexine & Cefalexine & & \\
\hline
\end{tabular}


Table 2: Urynalys, Bacteriological results and treatment of a captive young male Lesser anteater (Tamandua tetradactyla), SP, 2010

\section{URINALYSIS CASE 2}

\begin{tabular}{|c|c|c|}
\hline & $10 / 05 / 11$ & $25 / 05 / 11$ \\
\hline Volume & $8 \mathrm{ml}$ & $15 \mathrm{ml}$ \\
\hline Color & Citrine yellow & Citrine yellow \\
\hline Aspect & Clear & Clear \\
\hline Odor & Sui generis & Sui generis \\
\hline Density & 1022 & 1012 \\
\hline ph & 8.5 & 8.0 \\
\hline Nitrites & Negative & Negative \\
\hline Protein & Negative & Negative \\
\hline Glucose & Negative & +-- \\
\hline Ketones & Negative & Negative \\
\hline Urobilinogen & Negative & Negative \\
\hline Bilirrubin & Negative & Negative \\
\hline Hemoglobin & Negative & ++++ \\
\hline Erythrocytes & Rare & Rare \\
\hline Leukocytes & $3-6$ & Rare \\
\hline Cylinders & Absent & Ausentes \\
\hline Crystals & $\begin{array}{l}\text { Triple Phosphate } \\
\text { Crystals+-- }\end{array}$ & $\begin{array}{l}\text { Triple Phosphate } \\
\text { Crystals +-- }\end{array}$ \\
\hline Cells & $\begin{array}{l}\text { Vesicles +-- } \\
\text { Keratinized epithelial } \\
+--\end{array}$ & $\begin{array}{l}\text { Vesicles +-- } \\
\text { Keratinized } \\
\text { epithelial }\end{array}$ \\
\hline Bacteria & Positive & Negative \\
\hline Bacterial culture & $\begin{array}{l}\text { Staphylococcus sp } \\
\text { Non hemolytic } \\
\text { Streptococcus }\end{array}$ & Not performed \\
\hline Obs & - & - \\
\hline Treatment & Cefalexine & Not performed \\
\hline
\end{tabular}

\section{Results and discussion}

As observed by Sheets, 1986, the clinical findings on both animals are compatible with the signs observed in urinalysis from patients with infections in the lower urinary tract: bacteriuria, hematuria, pyuria and increased number of transitional epithelial cells in the urinary sediment. A higher alkalinity of the urine, a common alteration in urinary infections, was only observed in the second case.

The triple phosphate crystals can be considered normal, although commonly associated with alkaline urine and urinary infection (Jeff et al., 2005)

In both cases the urinary infection was caused by one, or more, species of bacteria. The bacteria that caused the infection were E.coli, Staphylococcus e Streptococcus, being compatible with what was described for urinary infections in other species (Ware, 2006).

Most bacterial infections of the lower urinary tract respond quickly to treatment with appropriate antibiotic (Ware, 2006). In the first case, the infection was controlled only 2 months after the beginning of antibiotic therapy, and after changing antibiotics. The second animal showed good response to a single treatment, not being necessary to repeat or change antibiotics. After the end of the antibiotic therapy, bacteria and leukocytes, indicative of infection, were not found in the second animal's urine.

The use of Apple cider vinegar and citric fruits juice was efficient for acidifying both animals' urine.

It was observed that, with the use of environmental enrichment items and time, the excessive licking of the genital behavior ceased, and relapse of the infection was not detected, suggesting that, as described by Soares et al., 2010, this tool can be used for maintaining the well-being for this species in captivity.

\section{Conclusions}

Excessive licking and suckling of the genital area maybe the predisposing factor to the urinary tract infection reported in those two animals. As perceived through personal communication with other institutions, cases of urinary infections in artificially raised babies are being observed frequently, and should be reported so that future studies can be done. A study on the normal bacterial flora of this species would be of great value, because through that we will be able to compare the bacteria of a normal flora, and the bacteria involved in cases of urinary infections.

Diagnosis and treatment of urinary tract infections in captive anteaters are of great importance to the maintenance of a minimum viable population of the species in captivity, since these animals present low intrinsic rates of population growth, and non treated infections can compromise their reproductive system. This can result in loss of genetic diversity in the captive population, as animals that don't have the possibility to reproduce can no longer contribute genetically to reproduction and conservation programs. Besides, treating the infection is crucial in the case of animals that have the chance of being released back into nature.

We emphasize the importance of the exchange of experiences and cases between professionals working with these animals, once there are still many aspects related to health and clinic that still need to be studied.

\section{Acknowledgements}

Thank you to the husbandry staff of the Aquário de São Paulo, and to DVM Flávia Miranda, from Projeto Tamanduá, for always being willing to help us and clearing up our doubts. 


\section{References}

BATISTA, M. K. Análise da variabilidade genética de diferentes populações de Tamandua tetradactyla (XENARTHRA) baseado em sequências da região da Alça - $D$ do genoma mitocondrial. Revista Científica - UFPA. v. 6, n. 16, 2006.

COSTA, L.P.; LEITE, Y.L.R.; MENDES, S.L.; DITCHFIELD, A.D. Conservação de Mamíferos no Brasil. Megadiversidade. v. 1, n. 1, p. 103-112, 2005.

DINIZ, L. S. M.; COSTA, E. O.; OLIVEIRA, P. M. A. Clinical disorders observed in anteaters (Myrmecophagidae, Edentata) in captivity. Veterinary research communication. Kluwer Academic Puplisher. Netherlands. v.19, p. 409-415, 1995.

JEFF, A.; SIMERVILLE, M.D.; WILLIAM C. MAXTED, M.D.; JOHN J.; PAHIRA, M.D. Urinalysis: A Comprehensive Review. American Family Physician. v. 71, n. 6, p. 1153-1162, 2005.

MEDRI, I. M.; MOURÃO, G. M.; RODRIGUES, F. H. C. Ordem Xenarthra. In: REIS, N. R.; PERACCHI, W. A.; PEDRO, W.A.; PASSOS DE LIMA, I. Mamíferos do Brasil. Universidade Estadual de Londrina. Londrina. 2006, p. 73-78.

CAHN, C.M., LINE, S. The Merck Veterinary Manual. Merck \& Co.,Inc. Pennsylvania. 2005, p. 2240.

MIRANDA, F.; COSTA, A. M. Xenarthra (Tamanduá, Tatu, Preguiça). In: CUBAS, Z. S.; SILVA, J. C. R.; CATÃO-DIAS, J. L. Tratado de Animais Selvagens. São Paulo: Roca, 2006, p. 402214.
PACHALLY, J.R.; Terapêutica por Extrapolação Alométrica. In: CUBAS, Z. S.; SILVA, J. C. R.; CATÃO-DIAS, J. L. Tratado de Animais Selvagens. São Paulo: Roca, 2006, p. 1215-1223.

SHEETS C, LYMAN JL. URINALYSIS. EMERG MED CLIN NORTH AM. v.4, 1986, p. 263-280.

SOARES, ANA.; REISFELD, LAURA.; REISFELD, ALICE.; SILVA, BRUNA SILVATTI FREITAS.; RIBEIRO, BRUNA.; SGAI, MANUELA GONÇALVES FRAGA GERONYMO.; PIZZUTTO, CRISTIANE SCHILBACH. Tipos de enriquecimento ambiental utilizados para um filhote de tamanduá-mirim (Tamandua tetradactyla) no Aquário de São Paulo. in: II Conferência Brasileira de Enriquecimento Ambiental. São Paulo. p. 19, 2010.

TAVARES, S. V.; KOENEMANN, J. G. Ocorrência de Tamandua tetradactyla (LINNAEUS, 1758) (XENARTHRA, MYRMECOPHAGIDAE) no município de Itaqui, fronteira oeste do Rio Grande do Sul, Brasil. Biodiversidade Pampeana v. 6, p. 3033, 2008.

WARE, WENDY. A. 2006. Manifestações Clínica do Trato Urinário. In: NELSON, R. W; COUTO, C.G. Medicina Interna de Pequenos Animais. Rio de Janeiro: Elsevier, 2006, p. 547-561.

WCS-World Conservation Society Brasil. Tamanduás. Disponível em: <http://programs.wcs.org/brazil/Wildlife/Anteaters/tabid/4125/ language/pt-BR/Default.aspx>. Acesso em 7 Set. 2011.

WETZEL, R. M. The identification and distribution of recent Xenarthra (=Edentata). In: MONGOMERY, G.G. The evolution and ecology of armadillos, sloths and vermilinguas. Smithsonian Institution. Press. Washington and London. 1985, p.5-21. 